\title{
Risk and protective factors associated with gang-involved youth in Trinidad and Tobago
}

\author{
Charles M. Katz ${ }^{1}$ and Andrew M. Fox ${ }^{1}$
}

Suggested citation

Katz CM, Fox AM. Risk and protective factors associated with gang-involved youth in Trinidad and Tobago. Rev Panam Salud Publica. 2010;27(3):187-202.

\begin{abstract}
Objectives. To examine the prevalence of gang involvement, the risk and protective factors associated with gang involvement, and the association between gang involvement and exposure to multiple risk and protective factors among school-aged youth in Trinidad and Tobago. Methods. A survey instrument was administered to 2206 students enrolled in 22 highrisk, urban public schools, from March-June 2006. It measured 30 risk factors and 13 protective factors within four domains: community, school, family, and peer-individual, plus levels of alcohol/drug use and delinquency.

Results. About $7.7 \%$ of youth reported being a gang associate; $6.8 \%$, a former gang member; and $6.2 \%$, a current gang member. Gang involvement was associated with perceived availability of handguns, residential mobility, having parents who favor antisocial behavior, early initiation of antisocial behavior, intention to use drugs, having antisocial peers, and having peers who use drugs. Those with social skills, belief in moral order, and interactions with prosocial peers were significantly less likely to self-report gang membership. Additionally, the probability of gang involvement increased as the number of risk factors increased.

Conclusions. Gang membership among public school youth is about as prevalent in Trinidad and Tobago as it is in the United States, Canada, and Western Europe, but further research is needed. Although risk factors associated with gang involvement were present in all four domains, peer-individual risk factors were disproportionately likely to be associated with gang status. The most effective gang prevention strategies might be those that focus on multiple risk factors, with an emphasis on peer-individual factors and promoting a "belief in moral order."
\end{abstract}

Key words Youth; adolescent behavior; social problems; mass behavior; risk factors; risk reduction behavior; Trinidad and Tobago; Caribbean Region.

Since the early 1990s, gangs, gang members, and gang-related problems have become increasingly recognized as a major public health problem in many areas of the world (1). Such is the extent of the issue that global public health and international development organizationsthe Pan American Health Organization, the Organization of American States

\footnotetext{
Center for Violence Prevention and Community Safety, Phoenix, Arizona. Send correspondence to Charles M. Katz, PhD, Arizona State University, Mail Code 3120, 500 N. 3rd Street, Suite 200, Phoenix, AZ, 85004-2135, United States of America; e-mail: ckatz@asu.edu.
}

(OAS), the Canadian International Development Agency (CIDA), and the United States Agency for International Development (USAID)—are allocating substantial resources for gang prevention and intervention programs (2-3, and Christopher Hernandez-Roy). ${ }^{2}$ This response has been largely a consequence of the growing realization that gang membership increases health risks for young people, and that individuals associated with gangs are sub-

\footnotetext{
2 Director, Department of Public Security, Organization of American States. Personal communication, 25 April 2009.
}

stantially more likely to experience negative health outcomes-violent injury, death, sexually-transmitted disease (STD), unwanted pregnancy, and drug and alcohol overdose (4).

The research of gangs and gangrelated phenomena has a long and extensive history in the United States of America; in Europe, the topic has also received increasing attention, but gangs have not been systematically examined elsewhere, much less in the Caribbean $(5,6)$. The lack of research in the Caribbean does not come as a surprise given that, as Caribbean scholars report, until 
recently little attention had been given to the health status of young people, and less so, to gang-related problems (7).

Though gang involvement can be difficult to assess, in large part because school-based methodologies and definitions of gang membership differ, recent findings indicate that the Caribbean may have a more extensive gang problem than that other more economicallydeveloped areas. In 2005, one of the few studies of gang prevalence in the Caribbean found that $17 \%-24 \%$ of males and $11 \%-16 \%$ of females reported gang involvement (8). Earlier research, funded by the World Bank, seems to support this view as well. A study of Jamaica found that in some communities, gang violence has created a "virtual 'war,' dominating and pervading all aspects of community life and restricting mobility within the area" (9). The same study concluded that gang activity in Jamaica was a primary contributor to that nation's homicide problem (9). Similar findings were reported for Trinidad and Tobago where, in 2008, the homicide rate rose to 44.34 per 100 000, placing it among the top most "murderous" nations (10); 63\% of these murders were attributed to gang members (11).

One approach to explaining, predicting, and addressing problem behaviors among youth is the risk factor prevention paradigm (12). Risk factors are those characteristics or symptoms, that when present, increase the odds that an individual will engage in problem behavior. Conversely, protective factors are those characteristics or symptoms, that when present, decrease the odds that an individual will engage in problem behavior $(7,13-17)$. The risk factor prevention paradigm, introduced to the study of behavior associated with crime and delinquency in 1992, categorizes risk and protective factors into four domains: community, school, family, and peer and individual. Within each of the domains are factors that have been empirically found to put an individual at risk or provide protection for problem behaviors such as substance abuse, delinquency, violence, teen pregnancy, and academic failure $(17,18)$.

Identifying the risk and protective factors associated with gang membership is important for at least two reasons. First, it helps structure an understanding of predictors associated with gang membership. The risk factor approach is very useful for isolating the most important factors related to gang membership and permits researchers to further diagnose, through more formal causal analyses, the root causes of gang membership (19). Second, the risk factor prevention paradigm helps structure prevention and intervention planning and programs, and helps focus resources on individuals with symptoms associated with the problem behavior $(19,20)$. Studies confirm this, specifically that it is a "userfriendly conceptual model" that can be easily translated into programmatic responses by mid-level policymakers and practitioners (21); and that risk and protection-focused prevention programs are repeatedly shown to be effective (22).

As noted above, studies conducted over several decades have identified a number of risk and protective factors associated with problem behavior; however, relatively few have examined the relationship between these factors and gang membership. A recent study synthesized and reviewed the body of literature on this topic and found that a total of 20 studies examined the association between risk factors and gang membership; they were almost exclusively conducted in the United States (20). Furthermore, most of the studies relied on bivariate analysis, were primarily descriptive in nature, and had not included controls for many of the factors known to be associated with joining a gang (20).

Consistent with the risk factor prevention paradigm, research has shown there to be multiple factors associated with gang joining. For example, studies have shown that community factors, such as availability of firearms (23) and/or drugs $(24,25)$ and number of neighborhood youth in trouble, increase a youth's risk of joining a gang. Youth with a low level of school commitment and low academic achievement have also been found to be significantly more likely to join a gang $(23,25)$. Family management has also been shown to be a risk factor associated with gang membership. Youth with parents who are less likely to supervise and monitor their children's activities and who express favorable attitudes toward antisocial behavior are more likely to join a gang $(23,25-28)$.

The literature suggests, however, that peer-individual factors, such as association with delinquent peers, early initiation to delinquent behavior, and possessing delinquent beliefs receive the strongest and most consistent support for being associated with gang membership (25, 27-29). Factors that lead to gang involvement are multifaceted, and may lead to gang involvement in one context, but not necessarily in another. Therefore, research is needed in various contexts to understand which factors might be globally applicable and which are unique to a specific scenario.

Accordingly, the goals of the present study were: to examine (a) the prevalence of gang involvement, (b) the risk and protective factors associated with gang involvement, and (c) the association between gang involvement and exposure to multiple risk and protective factors; to understand why Caribbean youth are joining gangs; and to provide information useful for designing prevention and intervention programs specifically for Caribbean nations.

\section{MATERIALS AND METHODS}

\section{Study area}

The Republic of Trinidad and Tobago is a two-island nation located about 11 $\mathrm{km}$ off the northeastern coast of Venezuela, between the Caribbean Sea and the North Atlantic Ocean. Trinidad and Tobago obtained independence from Great Britain in 1962; however, it remains a member of the Commonwealth of Nations, and it continues to be highly influenced by British culture and law. Although Trinidad and Tobago was once an agrarian society, over the past 30 years it become one of the wealthiest and most industrialized Caribbean countries, largely through petroleum production and the provision of regional finance. It currently reports one of the highest gross national incomes per capita and the second-fastest-growing economy in all the Caribbean, Central America, and South America (30). The nation is comprised of about 1.26 million people, of whom $40 \%$ are East Indian; 37.5\%, African; and $20.5 \%$ Afro-Indian.

Education in the Republic of Trinidad and Tobago is compulsory for all children 6-12 years of age. After the completion of primary school, students may either continue to secondary school, vocational studies, or craft training, or end their formal education (31). Just over $72 \%$ of youth (12-18 years of age) chose to continue their education, and of these, about $90 \%$ attend school on a daily basis (32). According to data provided by the Ministry of Education's Educational Planning Division, dropout rates among school-attending youth are a low 1.02\% (2005-2006 school year). Dropout rates did vary by gender and form (i.e., grade 
level), with $1.3 \%$ of males and $<1 \%$ of females dropping out. The highest dropout rate was found for form five (equivalent to 11th grade in the U.S. school system) males, with $2.34 \%$ dropping out. In just 10 years, Trinidad and Tobago experienced a 555\% increase in homicides, from 98 incidents in 1998, to 544 incidents in 2008. Most of the increase has been attributable to firearms-related violence (33) and gang warfare (9). The increase in violence has led to a significant increase in fear among residents in high-crime neighborhoods. For example, a study of one high-crime community found that " $56 \%$ of residents [believed that] the risk of being injured or killed because of crime [was] high, and many [felt] unsafe in their own neighborhood" (34).

\section{Study design}

The present study examines data from the Trinidad and Tobago Youth Survey (TTYS), one of several data collection initiatives funded by the Trinidad and Tobago Ministry of National Security for the purpose of diagnosing the nation's violent crime problem (34). Since the base rates for the behaviors in question were either unknown or expected to be low, a cross-sectional research design was developed to ensure a sufficient number of youth at high risk for delinquency and crime.

The target population for the TTYS was defined as third and fifth form (i.e., equivalent to 9 th and 11th grades in the U.S. system) students attending highrisk, urban, public schools. At the time of the study, the nation had a total of eight school districts with 92 public schools teaching third and fifth form students. Five of the eight districts were considered "urban"; therefore, for the purposes of the study, an "urban" school was defined as any school teaching third and fifth forms in one of the five urban school districts. Consequently, three districts were eliminated, including the school district of Tobago. The result was 67 public schools defined as "urban." Within this group, "high-risk schools" were defined as those identified by the Ministry of Education as having a disproportionate number of students living in high-crime areas, or a high number of delinquent incidents. As a result, 27 were identified as being at "high risk," and of these, $22(81.5 \%)$ agreed to participate in study's data collection efforts.

This response rate was fairly typical by international standards (35-38), but high when compared to other studies conducted in some developing nations (39). The 22 schools represent $24 \%$ of all public schools in Trinidad and Tobago, or about one-third of all public schools located in urban areas.

Additional analysis was also performed to confirm that the schools selected were indeed high-risk. Using police calls-for-service data provided by the Trinidad and Tobago Police Services (TTPS), neighborhood crime patterns were examined and compared to the Ministry of Education's high-risk schools. The results showed there to be high reliability between the two data sources.

\section{Survey instrument and data collection}

The survey instrument used in the present study was originally developed by the Social Development Research Group at the University of Washington (14). This instrument was chosen because its measures have been validated for use by the international community $(12,40-44)$. Key stakeholders at the Ministry of Education assisted in slightly modifying the instrument to reflect the local language and culture (i.e., monetary units, social activities, and organizations). The final version, the Trinidad and Tobago Youth Survey (TTYS), contained 238 items that measured 30 risk factors and 13 protective factors, within four domains: community, school, family, and peer/individual. The survey instrument also measured alcohol and drug use, and delinquency.

From March-June 2006, the survey was administered to 2552 students during their homeroom period at school. All students present in their homeroom on the day of the survey were given a copy of the survey instrument. Students were informed that if they did not wish to participate in the survey, they were to return the questionnaire "blank." Likewise, students were informed that if they did not want to answer a specific question, they could leave it blank. Therefore, our sample excludes youth not enrolled in school or absent from school on the survey day (due to illness, hospitalization, truancy/ skipping school, or detention). Regarding enrollment and absenteeism at participating schools, the Ministry of Education stated that data of this kind is not routinely collected, and that any available data is not necessarily accurate; whereas school administrators/officials estimated that on any given day, 5-10\% of students are absent.

Gang involvement served as the primary outcome variable for the present study. This was measured through two items: "Have you ever belonged to a gang;" followed by "Think of your four best friends. In the past year, how many of your best friends have been a member of a gang?" Guided by prior research, respondents were categorized into four groups according to their responses. Those who reported currently being in a gang were categorized as "current gang members"; those who reported having been in a gang in the past were categorized as "former gang members"; those who reported having two or more friends in a gang were categorized as "gang associates"; and those who did not self-report gang involvement were categorized as "non-gang members." Note that although some academics have argued that a dichotomous measure of gang membership (i.e., past and current members in one category and non-gang members in another) is more analytically parsimonious, for this study it would not have allowed for the possibility of qualitative differences based on the extent of an individual's gang involvement. In particular, the very nature of dichotomous measurement might mask important behavioral distinctions regarding the extent of gang association, which in turn, could result in fallacious findings and policy recommendations (45).

As a form of validation, all former and current gang members were asked additional questions about the organizational structure of their gang. About 95\% of both former and current members indicated that their gang possessed one or more of the following organizational qualities: name, territory/turf, a leader, regular meetings, rules, consequence/punishment for broken rules, special colors/signs/symbols/clothing, contributions of money to the gang, drug sale income, kidnapping, and/or other crimes. The average number of organizational qualities reported by each former and current member was 4.5. Based on these results, respondents were indicating membership to a gang and not just an association with a delinquent peer network.

A total of 30 risk factors and 13 protective factors were examined to identify relationships with gang involvement. Table 1 presents the risk and protective factors and each of their properties by domain. Guided by previous research, a 
TABLE 1. Descriptive statistics for risk and protective factors among youth, Trinidad and Tobago, 2006

\begin{tabular}{|c|c|c|c|c|c|}
\hline Domains and scales & Items & Range & Mean & $\begin{array}{l}\text { Standard } \\
\text { deviation }\end{array}$ & $\begin{array}{c}\text { Cronbach's } \\
\text { alpha }^{a}\end{array}$ \\
\hline \multicolumn{6}{|l|}{ Risk factors } \\
\hline \multicolumn{6}{|l|}{ Community } \\
\hline Low neighborhood attachment & 2 & $1-4$ & 2.084 & 0.988 & 0.612 \\
\hline High community disorganization & 5 & $1-4$ & 1.981 & 0.683 & 0.685 \\
\hline Mobility & 1 & $1-3$ & 1.393 & 0.795 & $N A^{b}$ \\
\hline Laws and norms favorable to drugs & 5 & $1-4$ & 2.512 & 0.711 & 0.709 \\
\hline Perceived availability of handguns & 1 & $1-4$ & 1.949 & 1.244 & NA \\
\hline Perceived availability of drugs & 2 & $1-4$ & 2.469 & 1.144 & 0.741 \\
\hline \multicolumn{6}{|l|}{ School } \\
\hline Academic failure & 1 & $1-4$ & 2.101 & 0.568 & NA \\
\hline Low commitment to school & 7 & $1-5$ & 1.864 & 0.518 & 0.627 \\
\hline \multicolumn{6}{|l|}{ Family } \\
\hline Family history of antisocial behavior & 8 & $1-5$ & 2.647 & 1.025 & 0.773 \\
\hline Poor family management & 8 & $1-4$ & 1.971 & 0.696 & 0.787 \\
\hline Family conflict & 3 & $1-4$ & 2.448 & 0.878 & 0.676 \\
\hline Parental attitudes favorable towards drug use & 1 & $1-4$ & 1.079 & 0.360 & NA \\
\hline Parental attitudes favorable towards alcohol use & 1 & $1-4$ & 1.552 & 0.874 & NA \\
\hline Parental attitudes favorable towards antisocial behavior & 3 & $1-4$ & 1.375 & 0.514 & 0.644 \\
\hline \multicolumn{6}{|l|}{ Peer-individual } \\
\hline Rebelliousness & 3 & $1-4$ & 1.888 & 0.833 & 0.726 \\
\hline Early initiation of antisocial behavior & 1 & $0-8$ & 1.419 & 2.475 & NA \\
\hline Early initiation of drug use & 1 & $0-8$ & 0.560 & 1.782 & NA \\
\hline Early initiation of alcohol use & 2 & $0-8$ & 2.869 & 2.270 & 0.608 \\
\hline Attitudes favorable to antisocial behavior & 5 & $1-4$ & 1.405 & 0.493 & 0.747 \\
\hline Attitudes favorable to drug use & 1 & $1-4$ & 1.268 & 0.661 & NA \\
\hline Attitudes favorable to alcohol use & 1 & $1-4$ & 1.749 & 0.943 & NA \\
\hline Intention to use drugs & 1 & $1-4$ & 1.198 & 0.571 & NA \\
\hline Intention to use alcohol & 1 & $1-4$ & 2.202 & 1.087 & NA \\
\hline Perceived risk of drug use & 3 & $1-4$ & 1.839 & 0.838 & 0.750 \\
\hline Antisocial peers & 6 & $0-4$ & 0.413 & 0.565 & 0.650 \\
\hline Peers use drugs & 1 & $0-4$ & 0.633 & 1.241 & NA \\
\hline Peers use alcohol & 1 & $0-4$ & 1.496 & 1.612 & NA \\
\hline Rewards for antisocial involvement & 3 & $1-5$ & 1.961 & 1.190 & 0.818 \\
\hline Depression & 4 & $1-4$ & 2.268 & 0.833 & 0.841 \\
\hline Sensation seeking & 3 & $1-6$ & 2.566 & 1.174 & 0.521 \\
\hline \multicolumn{6}{|l|}{ Protective factors } \\
\hline \multicolumn{6}{|l|}{ Community } \\
\hline Opportunities for prosocial involvement & 3 & $1-4$ & 2.779 & 1.238 & 0.641 \\
\hline Rewards for prosocial involvement & 3 & $1-4$ & 2.635 & 0.963 & 0.769 \\
\hline \multicolumn{6}{|l|}{ School } \\
\hline Opportunities for prosocial involvement & 5 & $1-4$ & 2.861 & 0.712 & 0.722 \\
\hline Rewards for prosocial involvement & 4 & $1-4$ & 2.782 & 0.766 & 0.708 \\
\hline \multicolumn{6}{|l|}{ Family } \\
\hline Family attachment & 4 & $1-4$ & 2.685 & 0.822 & 0.700 \\
\hline Opportunities for prosocial involvement & 3 & $1-4$ & 2.745 & 0.897 & 0.714 \\
\hline Rewards for prosocial involvement & 4 & $1-4$ & 2.806 & 0.730 & 0.644 \\
\hline \multicolumn{6}{|l|}{ Peer-individual } \\
\hline Religiosity & 1 & $1-4$ & 2.857 & 1.043 & NA \\
\hline Social skills & 4 & $1-4$ & 3.050 & 0.638 & 0.524 \\
\hline Belief in the moral order & 4 & $1-4$ & 3.198 & 0.633 & 0.770 \\
\hline Prosocial involvement & 1 & $0-7$ & 2.464 & 2.274 & NA \\
\hline Rewards for prosocial involvement & 1 & $1-5$ & 2.791 & 1.355 & NA \\
\hline Interaction with prosocial peers & 5 & $0-4$ & 2.480 & 0.931 & 0.549 \\
\hline
\end{tabular}

a Average alpha $=0.691$

${ }^{b}$ NA: Not applicable.

score for each respondent was determined by averaging responses across items within each factor (some items had to be reverse-coded before scale construction). Scales were initially constructed using all items used by the Social Development Research Group. After scale construction, however, some of the scales were altered (i.e., items were dropped) due to lack of internal reliability. In the end, all multiple-item scales used in the multivariate analysis demonstrated internal reliability (as measured by Cronbach's alpha). Appendix A de- scribes the items and response categories used to construct risk and protective factor scales.

Respondents who scored in the upperthird on a particular risk or protective factor were coded as " 1 ," indicating that the respondent was at elevated risk (or 
protection) for the factor. Respondents who scored elsewhere in the distribution were coded as " 0 ," indicating that they were at low risk (or protection) for the factor. The authors noted that there are advantages and disadvantages associated with dichotomizing predictor variables; however, prior research indicates that dichotomizing risk and protective factors is beneficial as far as it increases interpretability (i.e., meaningful interpretations of odds ratios) and reduces the error-associated skewed variables. Additionally, while the use of dichotomized predictors limits the amount of variation in a variable, it rarely affects the substantive findings (46). For an explanation of the cut point chosen for the present study, see Bond et al. (47).

To examine the association of multiple risk and protective factors on gang association, the number of elevated risk and protective factors attributed to each respondent were counted. Because there were 30 risk factors and 13 protective factors, a respondent's cumulative risk factor score could range from 0-30, and the cumulative protective factor score, from $0-13$.

\section{Analysis}

Bivariate analyses were used to examine the prevalence of gang involvement by gender, ethnicity, and age, and to assess the relationship of multiple risk and protective factors with gang involvement. Multinomial logistic regression was used to examine the risk and protective factors associated with gang involvement. Multinomial logistic regression was used because the outcome measure was a nominal level variable. In multinomial logistic regression, one category is chosen as the comparison (or base) category, which is contrasted with all other response categories. In the present study, we have four response categories: never in a gang, gang associate, former gang member, and current gang member. "Never in a gang" was chosen as the comparison category, to be contrasted with the other three responses. Additionally, given that surveys were collected across 22 schools, STATA 10.0 (StataCorp LP, Texas, United States) was used to calculate robust standard errors to account for clustering by school (48). Before interpreting the findings, multicollinearity diagnostics were conducted. The diagnostic tests indicated that multicollinearity was not a problem; no vari- ance inflation factor was greater than 2 and no condition indices were greater than 10, well below levels that would suggest collinearity (49).

\section{RESULTS}

Of the 2552 survey instruments administered to students, $6.9 \%$ were excluded for invalid data. For example, near the end of the survey all respondents were asked, "How honest were you in filling out this survey?" If the respondent did not answer the question, or indicated "I was not honest at all," that survey was eliminated from the dataset $(n=85)$. Likewise, for respondents reporting use of a nonexistent drug (phenoxydine), their data were excluded from analysis $(n=91)$. Furthermore, not all students who took the survey completed every question. Imputation of missing data was conducted using PRELIS 2.0 (Scientific Software International Inc., Illinois, United States) similar response pattern imputation. Research has supported this method of imputation, and there is evidence that it introduces less bias than listwise deletion and mean replacement (50). After the above protocols were applied, 2206 surveys remained in the dataset and were used for the present study.

The final sample contained respondents ranging from 11-19 years of age, with a mean age just over 15 years. About $22 \%$ of the respondents were 14 years of age or younger; $38.7 \%$ were 15 ; $27.7 \%$ were 16 ; and $13.6 \%$ were 17 or older. Females comprised $59.6 \%$ of the sample. In terms of ethnicity, $41.2 \%$ of the respondents indicated that they were African; $22.8 \%$, East Indian; and $15.3 \%$, Afro-Indian. For purposes of the analysis, the 17 respondents who reported being Chinese and the 18 who reported being White were combined with those who reported their ethnicity as "other" $(n=423)$; therefore, the ethnicity of $20.8 \%$ of study respondents was coded as "other." East Indian students may have been underrepresented in the study sample because, according to the Ministry of Education, the East Indian population tends to be wealthier than the African population and therefore more likely to enroll in private schools, which were not included in this study (telephone communication with Marlene Charles, Ministry of Education, April 2006).

\section{Gang prevalence}

Of the respondents in our sample, the majority $(79.4 \%)$ reported never having been in a gang; $7.7 \%$ reported being a gang associate; $6.8 \%$, being a former gang member; and $6.2 \%$, a current gang member (Table 2). Analysis indicated that gang status varied significantly by gender, with more males (8.9\%) than females $(4.4 \%)$ reporting being a current gang member. Likewise, more males $(10.4 \%)$ than females $(5.8 \%)$ reported being a gang associate, and more than twice as many males $(10.1 \%)$ as females $(4.5 \%)$ reported being a former gang member.

Gang association also varied, although not significantly $(P=0.051)$, by ethnicity. Those identifying themselves as belonging to the ethnic group "other"

TABLE 2. Bivariate analysis of gang involvement by select demographic characteristics in Trinidad and Tobago, 2006

\begin{tabular}{|c|c|c|c|c|c|}
\hline & Never & $\begin{array}{c}\text { Gang } \\
\text { associate }\end{array}$ & $\begin{array}{l}\text { Former } \\
\text { member }\end{array}$ & $\begin{array}{l}\text { Current } \\
\text { member }\end{array}$ & Total \\
\hline & $\%$ & $\%$ & $\%$ & $\%$ & No. \\
\hline \multicolumn{6}{|l|}{ Gender $^{a}$} \\
\hline Female & 85.3 & 5.8 & 4.5 & 4.4 & 1314 \\
\hline Male & 70.6 & 10.4 & 10.1 & 8.9 & 892 \\
\hline \multicolumn{6}{|l|}{ Ethnicity } \\
\hline African & 80.0 & 8.0 & 5.6 & 6.4 & 909 \\
\hline East Indian & 82.1 & 5.8 & 6.4 & 5.8 & 502 \\
\hline Afro/Indian & 77.7 & 7.4 & 10.4 & 4.5 & 337 \\
\hline Other & 76.4 & 9.2 & 6.8 & 7.6 & 458 \\
\hline \multicolumn{6}{|l|}{$\mathrm{Age}^{\mathrm{a}}$} \\
\hline Mean & 15.3 & 15.4 & 15.7 & 15.4 & $N A^{b}$ \\
\hline Standard Deviation & 1.05 & 1.08 & 1.06 & 1.05 & NA \\
\hline Total & 79.4 & 7.7 & 6.8 & 6.2 & 2206 \\
\hline
\end{tabular}

a $P<0.01$

${ }^{\mathrm{b}} \mathrm{NA}$ : Not applicable. 
were most likely to report current gang membership (7.6\%); followed by Africans (6.4\%); East Indians (5.8\%); and Afro-Indians (4.5\%). About $10 \%$ of Afro-Indians reported being former gang members, as did $6.8 \%$ of "others"; $5.6 \%$ of Africans; and $6.4 \%$ of East Indians. About $9 \%$ of those in the "other" ethnic group reported being gang associates; as did $8 \%$ of Africans; $7.4 \%$ of Afro-Indians; and $5.8 \%$ of East Indians. Gang affiliation was significantly associated with age, with former gang members being significantly older than the other three categories (current gang members, gang associates, and nongang members).

\section{Risk and protective factors associated with gang status}

While all of the risk and protective factors that were shown in Table 1 were in- cluded in our analyses, Table 3 presents findings for those variables that were significantly associated with the outcome variable, i.e., the significant relationships found between gang status and risk and protective factors (results not presented in Table 3 are available from the corresponding author upon request).

Analyses indicated that, within the community domain, two risk factors were associated with gang status: residential mobility and availability of handguns. Respondents who reported residential mobility were more likely to be former gang members, rather than nongang members; and those reporting availability of handguns in their communities were more likely to be current gang members (odds ratio $(\mathrm{OR})=2.503$ ) or former gang members $(\mathrm{OR}=2.864)$, rather than non-gang members.

Within the school domain, one risk factor was significantly related to gang involvement, with former gang members being less likely to report low commitment to school $(\mathrm{OR}=0.611)$.

Within the family domain, one risk factor was associated with gang status, that is, the odds of being a gang associate increased by about $45 \%$ for those who reported parental attitudes favorable toward antisocial behavior.

In the peer-individual domain, five risk factors (a-e) were significantly associated with gang status. Compared with non-gang members, gang associates were significantly more likely to report an elevated risk for (a) antisocial peers $(\mathrm{OR}=6.255)$, $(\mathrm{b})$ peer drug use $(\mathrm{OR}=$ 2.767), and (c) peer alcohol use ( $\mathrm{OR}=$ 1.745); and former gang members reported being at greater risk for (d) early initiation of antisocial behavior ( $\mathrm{OR}=$ 2.828) and (e) intention to use drugs $(\mathrm{OR}=1.921)$. Current gang members concurred by reporting an elevated risk

TABLE 3. Multinomial analysis of risk and protective factors associated with gang status among youth in Trinidad and Tobago, 2006

\begin{tabular}{|c|c|c|c|c|c|c|}
\hline & \multicolumn{2}{|c|}{$\begin{array}{l}\text { Gang associate } \\
\quad(n=169)\end{array}$} & \multicolumn{2}{|c|}{$\begin{array}{l}\text { Former gang member } \\
\qquad(n=149)\end{array}$} & \multicolumn{2}{|c|}{$\begin{array}{l}\text { Current gang member } \\
\qquad(n=137)\end{array}$} \\
\hline & OR & $95 \% \mathrm{Cl}$ & OR & $95 \% \mathrm{Cl}$ & OR & $95 \% \mathrm{Cl}$ \\
\hline \multicolumn{7}{|l|}{ Risk Factors } \\
\hline \multicolumn{7}{|l|}{ Community domain } \\
\hline Mobility & 1.106 & $0.687,1.781$ & $1.782^{\mathrm{c}}$ & $1.254,2.533$ & 1.012 & $0.634,1.616$ \\
\hline Perceived availability of handguns & 1.230 & $0.733,2.062$ & $2.864^{\mathrm{C}}$ & $2.125,3.860$ & $2.530^{\mathrm{C}}$ & $1.606,3.984$ \\
\hline Low commitment to school & 1.044 & $0.717,1.519$ & $0.611^{\mathrm{b}}$ & $0.382,0.979$ & 0.872 & $0.506,1.501$ \\
\hline \multicolumn{7}{|l|}{ Family domain } \\
\hline $\begin{array}{l}\text { Parental attitudes favorable towards antisocial behavior } \\
\text { Peer-individual domain }\end{array}$ & $1.452^{b}$ & $1.010,2.086$ & 1.272 & $0.644,2.513$ & 0.948 & $0.595,1.512$ \\
\hline Early initiation of antisocial behavior & 1.149 & $0.780,1.690$ & $2.828^{c}$ & $1.961,4.077$ & $1.717^{b}$ & $1.083,2.721$ \\
\hline Intention to use drugs & 1.170 & $0.774,1.765$ & $1.924^{\mathrm{c}}$ & $1.202,3.078$ & $3.163^{c}$ & $2.032,4.923$ \\
\hline Antisocial peers & $6.255^{\mathrm{c}}$ & $4.300,9.098$ & 1.195 & $0.676,2.114$ & $2.328^{c}$ & $1.466,3.695$ \\
\hline Peers use drugs & $2.767^{c}$ & $1.664,4.598$ & 1.146 & $0.778,1.688$ & $1.638^{\mathrm{b}}$ & $1.042,2.575$ \\
\hline \multicolumn{7}{|l|}{ Protective Factors } \\
\hline \multicolumn{7}{|l|}{ Community domain } \\
\hline Rewards for prosocial involvement & $1.697^{b}$ & $1.057,2.723$ & 0.947 & $0.655,1.369$ & 1.063 & $0.706,1.601$ \\
\hline \multicolumn{7}{|l|}{ School domain } \\
\hline Opportunities for prosocial involvement & 1.443 & $0.793,2.622$ & 0.854 & $0.518,1.410$ & $1.921^{b}$ & $1.050,3.513$ \\
\hline \multicolumn{7}{|l|}{ Family domain } \\
\hline Opportunities for prosocial involvement & 1.495 & $0.904,2.470$ & $1.535^{\mathrm{b}}$ & $1.036,2.275$ & 0.807 & $0.440,1.482$ \\
\hline \multicolumn{7}{|l|}{ Peer-individual domain } \\
\hline Social skills & 1.017 & $0.708,1.459$ & $0.442^{\mathrm{c}}$ & $0.247,0.790$ & $0.448^{b}$ & $0.228,0.879$ \\
\hline Belief in the moral order & 0.672 & $0.448,1.008$ & 0.716 & $0.406,1.263$ & $0.617^{b}$ & $0.388,0.980$ \\
\hline Rewards for prosocial involvement & 0.753 & $0.474,1.194$ & $1.584^{b}$ & $1.034,2.426$ & 1.161 & $0.762,1.77$ \\
\hline Interaction with prosocial peers & 1.074 & $0.687,1.677$ & $0.491^{\mathrm{c}}$ & $0.302,0.798$ & 0.922 & $0.574,1.481$ \\
\hline Model Chi-square (df) & \multicolumn{6}{|c|}{$753.02^{c}(129)$} \\
\hline McFadden $\mathrm{R}^{2}$ & \multicolumn{6}{|c|}{0.232} \\
\hline
\end{tabular}

a Risk and protective factors not presented in this table were found to be not significantly related to gang status, but were controlled for in this model. Full table available upon request (see footnote 1 ).

${ }^{b} P<0.05$.

${ }^{c} P<0.01$ (based on robust standard error for clustering on school).

$d$ The base category is "Never been in a gang" and the total $n=2206$. 
for (a) antisocial peers (OR 2.328), (b) peer drug use (OR 1.638), (d) early initiation of antisocial behavior $(\mathrm{OR}=1.717)$, and (e) intention to use drugs (OR 3.163).

Analysis also revealed several protective factors associated with gang joining. For example, within the individual dosignificantly related to gang involvement. Current gang members were less likely to report the protection of (a) social skills (OR $=0.448)$ and $(b)$ belief in moral order $(\mathrm{OR}=0.617)$; and former gang members reported (c) less interaction with prosocial peers $(\mathrm{OR}=0.491)$, as well as (d) fewer social skills (OR $=0.442$ ).

Reporting rewards for prosocial involvement, however, increased a respondent's odds of being a former gang member by about $58 \%$. In the community domain, gang associates were found to be significantly more likely than nongang members to report rewards for prosocial involvement within their communities; and in the school domain, current gang members were more likely to report opportunities for prosocial involvement $(\mathrm{OR}=1.924)$. Within the family domain, the odds of being a former gang member $(\mathrm{OR}=1.535)$ increased for those respondents who reported having the protection of opportunities for prosocial involvement.

Overall, there was good model fit for the multinomial logistic regression model presented in Table 3. There was a significant Chi-square $\left(\chi^{2}=753.02\right.$ with 129 degrees of freedom; $P<0.001)$. Additionally, the model effect size indicates that the risk and protective facmain, four protective factors $(\mathrm{a}-\mathrm{d})$ were

tors explain a substantial portion of the variance in gang status (Nagelkerke $\left.R^{2}=0.376\right)$.

\section{Effects of multiple risk and protective factors on gang involvement}

Table 4 presents findings on the association between gang involvement and exposure to multiple risk and protective factors. Analyses indicated that overall, $46.6 \%$ of respondents who reported being exposed to a high number of risk factors (17 or more) were not gang members (see row \%). Still, those who reported exposure to a high number of risk factors were more likely to be ganginvolved (see column \%), and those who reported exposure to a low number of risk factors were less likely to be.

A similar trend was observed for the relationship between multiple protective factors and gang involvement. Respondents who reported exposure to a high number of protective factors were less likely to report gang involvement. For example, about $35 \%$ of those who had never been in a gang reported being exposed to seven or more protective factors; only about $17 \%$ of current gang members reported this level of exposure (see column \%). Likewise, 51.1\% of current gang members and $37 \%$ never in a gang reported exposure to two or fewer protective factors. A Chi-square test for significance indicated that, in fact, the cumulative number of risk factors and the cumulative number of protective factors vary significantly by gang involvement.

TABLE 4. Bivariate analysis of accumulation of risk and protective factors by gang involvement in Trinidad and Tobago, 2006

\begin{tabular}{|c|c|c|c|c|c|c|c|c|}
\hline & \multicolumn{2}{|c|}{ Never } & \multicolumn{2}{|c|}{ Gang associate } & \multicolumn{2}{|c|}{ Former member } & \multicolumn{2}{|c|}{ Current member } \\
\hline & Col \% & Row \% & Col \% & Row \% & $\mathrm{Col} \%$ & Row \% & Col \% & Row \% \\
\hline \multicolumn{9}{|c|}{ Number of elevated risk factors ${ }^{a}$} \\
\hline 0 to 4 & 21.9 & 97.7 & 3.0 & 1.3 & 2.0 & 0.8 & 0.7 & 0.3 \\
\hline 5 to 8 & 29.2 & 90.1 & 15.4 & 4.6 & 11.4 & 3.0 & 9.5 & 2.3 \\
\hline 9 to 12 & 24.7 & 81.8 & 24.3 & 7.8 & 19.5 & 5.5 & 19.0 & 4.9 \\
\hline 13 to 16 & 16.1 & 68.3 & 32.5 & 13.3 & 24.8 & 9.0 & 28.5 & 9.4 \\
\hline$\geq 17$ & 8.1 & 46.6 & 24.9 & 13.8 & 42.3 & 20.7 & 42.3 & 19.0 \\
\hline \multicolumn{9}{|c|}{$\begin{array}{l}\text { Number of elevated protective } \\
\text { factors }^{b}\end{array}$} \\
\hline 0 to 2 & 13.0 & 78.8 & 11.2 & 6.6 & 15.4 & 8.0 & 13.9 & 6.6 \\
\hline 3 to 4 & 24.0 & 72.3 & 32.0 & 9.3 & 37.6 & 9.6 & 37.2 & 8.8 \\
\hline 5 to 6 & 27.8 & 78.8 & 29.6 & 8.1 & 25.5 & 6.2 & 31.4 & 7.0 \\
\hline 7 to 8 & 20.2 & 83.5 & 18.3 & 7.3 & 14.8 & 5.2 & 12.4 & 4.0 \\
\hline$\geq 9$ & 15.0 & 89.2 & 8.9 & 5.1 & 6.7 & 3.4 & 5.1 & 2.4 \\
\hline
\end{tabular}

a Chi-square $=382.643, P<0.001$.

${ }^{\mathrm{b}}$ Chi-square $=44.913, P<0.001$.

\section{DISCUSSION}

The study results suggest that gang membership is about as prevalent in Trinidad and Tobago as it is in samples of public schools in Canada, the United States, and Western Europe, but perhaps lower than that of some other Caribbean nations (20).

Until recently, research on gang prevalence had been conducted primarily in the United States, but during the last decade, researchers from nations such as Canada, the United Kingdom, Germany, and the Netherlands have begun to examine the issue with schoolbased samples $(5,20)$. Prevalence estimates have varied depending on the researcher's definition of a gang and the sampling strategy employed, but work using unrestrictive definitions of a gang and public school-based samples, as used in the present study, has yielded fairly consistent prevalence rates (20).

The gang prevalence rates found in the current study, broken down by select sociodemographic characteristics, were also similar to those of developed nations, with males and older respondents being more likely to report gang involvement (20). However, it is important to note that our gang membership prevalence rates are inconsistent with at least one study (8) that reported $17-24 \%$ of males and $11-16 \%$ of females in Caribbean public schools were either former or current gang members. While said study focused on students in Jamaica and eight small island nations across the Caribbean, the difference in gang membership prevalence rates might have been the result of inter-island differences, the wording of survey questions, or sampling protocol. For instance, one study may have found higher gang member prevalence rates because $60 \%$ of its sample was Jamaican students $(7,8)$. While there has been little systematic research on the topic, Jamaica is believed to have one of the worst gang problems in the Western Hemisphere (9).

The present study found that although risk factors associated with gang involvement were present in all four domains, the influence of the respective domains was unequal. For example, school-related risk factors, for the most part, were not significantly associated with gang involvement. While some prior research has shown that low commitment to school and low academic achievement is related to gang joining 
$(23,25)$, these findings are consistent with a larger body of research that has shown the relationship not to be significant (51) or have determined the relationship to be inconclusive $(52,53)$.

Our analyses indicated that two community risk factors were associated with gang joining: perceived availability of handguns and a high level of residential mobility. Perceived availability of handguns was found to be significantly associated with former and current gang membership. The fact that former and current gang members were more likely to report perceived availability of handguns in their communities is not surprising. Prior research has shown that gang members are more likely than non-gang members to possess and to use guns and that their peers are more likely to possess and use handguns. This might account for why gang members perceived handguns to be more widely available than non-gang members in our sample. Alternatively, a large body of research indicates that a sizable proportion of gang members joined their gang for protection $(20,54,55)$. In communities with a high number of handguns, youths may join gangs out of fear. On the other hand, the relationship between perceived availability of guns and gang involvement may, in fact, be because gang members are more likely to carry a gun. Further research to examine this relationship is recommended.

Regarding residential mobility, youth who lived in neighborhoods with a high level of mobility were significantly more likely to report being former gang members. A key tenet of social disorganization theory is that communities characterized by high levels of mobility are also characterized by lower levels of informal social control due to a reduced capacity to develop social cohesion and mutual trust among residents. Thus, gangs and violence are more likely to emerge in communities with high levels of mobility because the values and norms that are essential for informal social control at the neighborhood level are missing (56-58).

Few of the family risk factors were found to be associated with gang joining. The only risk factor within the family domain that was significantly associated with gang status was that youth who associated with gang members were significantly more likely to report having parents with attitudes that favored antisocial behavior. It might be that youth with parents who favor antisocial behav- ior face fewer parental consequences for developing friendship networks with troublesome youth, such as gang members. While parental supervision has been frequently found to be associated with gang status in prior research $(23,25,28$, $29)$, it was not significantly related to gang joining among our sample of youth in Trinidad and Tobago. A recent review of the literature on risk behaviors among Caribbean youth showed that few studies have examined the relationship between parental supervision and risky behavior, and the few that have, have not found the relationship to be significant (60-only risky sexual behavior was associated with low parental supervision; substance abuse, teenage pregnancy, sexually-transmitted infections and HIV/AIDS, mental health, violence/delinquency, and eating disorders/obesity were not).

Peer-individual risk factors were more likely to be associated with gang status, than were risk factors in other domains. Specifically, the study found a robust relationship between gang status and early initiation of antisocial behavior, intention to use drugs, having antisocial peers, and having peers who use drugs. Our findings are consistent with prior longitudinal and cross-sectional studies that have repeatedly shown that youth who engage/intend to engage in delinquency and drug use are significantly more likely to join a gang, than those who do not $(21,26,59)$. Likewise, the body of research has repeatedly demonstrated that gang joining is strongly associated with having delinquent peer networks and negative peer influences-net of other risk and protective factors-and that peer influences exert a much stronger influence on gang joining than family, community, and school factors. As a consequence, our analysis, combined with research conducted in other nations, suggests that the influence of the peerindividual domain on gang joining is strong.

Another major finding of the present study was that some protective factors were associated with gang status, but not always in the hypothesized direction. Our analyses indicated that, in general, those with social skills, belief in moral order, and who had interaction with prosocial peers were significantly less likely to have self-reported being a current or former gang member. Of particular interest was our finding that rewards and opportunities for prosocial involvement were significantly related to gang involvement. Gang associates were sig- nificantly more likely than non-gang members to self-report living in communities with rewards for prosocial involvement. Former gang members, when contrasted to non-gang members, were significantly more likely to report having more family opportunities for prosocial involvement and to be rewarded by their peers for prosocial involvement. Current gang members were also significantly more likely than non-gang members to have opportunities for prosocial involvement in their schools. To help interpret these findings, a small, but important body of literature suggests that some group-based activity can increase participation in gangs (20).

Over the last three decades, several prevention and social intervention programs have relied on programs that attempts to steer at-risk youth away from delinquency, crime, and gangs by encouraging them to pursue more sociallyacceptable activities, such as sports teams, club activities, and other prosocial group-based events. While most of the research examining these strategies found that they were ineffective in reducing gang membership as well as gang crime (60-63), some of this research demonstrated that these programs lead to an increase in gang membership and gang violence $(64,65)$.

While this study's data do not allow the underlying causal mechanisms at play to be examined, it may be that atrisk youth cluster toward group activities in Trinidad, which in turn has a "peer contagion effect." Peer contagion is believed to operate through a process of socialization whereby delinquent youth co-opt at-risk youth through verbal and non-verbal communication (66, 67). Peer contagion effects have been linked to drug and alcohol use, delinquency, violence, and gang joining (67-70). It might be that at-risk youth who participate in group-based activities in Trinidad increase their chances for joining a gang.

Lastly, the probability of gang association was found to increase as the number of risk factors increased. Current gang members were disproportionately in the highest cumulative risk category; next were former gang members, followed by gang associates, and those never in a gang. Our findings are consistent with prior research that reported that exposure to multiple risk factors, regardless of the domain, were associated with negative health outcomes, such as depression and substance use (45). 
Although not often discussed in the literature, the present study also found that exposure to multiple risk factors did not necessarily mean that a youth would be gang-involved. In fact, more than half of youth who reported the presence of a high number of risk factors were not involved in a gang. This finding indicates that the influence of risk factors on gang joining can be mediated, and that some protective factors can inoculate youth against gang involvement.

\section{Study limitations}

Before the interpretation of the findings is complete, four limitations must be noted. First, the findings should not be generalized to other countries in the Caribbean or proximate nations. Numerous studies have demonstrated that every community's gang problem is unique and might be dissimilar to the problem in other communities (5).

Second, the present study relied on a cross-sectional research design using measures of risk and protective factors shown in prior research to predict gang membership, delinquency, and drug use; however, the results should not be interpreted as implying causality. The cross-section design employed in the present study does not permit us to make statements about the existence or direction of the factors that lead to gang involvement, only that particular factors were or were not associated with gang involvement.

Third, the present study employs the risk and protective factor paradigm that has been characterized by some academics as limited. Specifically, the paradigm has been criticized for its overemphasis of proximate individual factors and its under-emphasis of social and structural factors (71).

Fourth, the study may suffer from sample selection bias. The use of a highrisk public school sample may have necessarily confined the variability of respondent's exposure to some risk and protective factors, particularly in the school domain. Also, the prevalence estimates of gang membership might be under-estimating the scope and nature of the problem because gang members might be less likely to enroll in and attend school. Some prior research has shown that increased gang activity is related to lower academic resilience (72).

Despite its limitations, to the authors' knowledge, this is the first study in the Caribbean to examine risk and protec- tive factors associated with gang membership in a sample of public school youth. The study analysis yielded three important findings: first, gang prevalence among Trinidadian school youth is similar to rates found in the United States and Europe, but lower than previous Caribbean estimates; second, although risk factors associated with gang involvement were present in all four domains, peer-individual risk factors were disproportionately likely to be associated with gang status; and third, the probability of gang involvement increased with the accumulation of risk factors and decreased with the accumulation of protective factors.

\section{Research recommendations and policy implications}

This study's findings have several implications for policy and future research. Researchers in the near future should conduct comparative research between nations using a similar methodology to further understand the scope and nature of gang problems, and how they contribute to public health problems, such as violence and drug use. It is important to understand whether predictors of gang phenomena are universal, regardless of economic, political, and other macro-level forces, and whether current theoretical propositions for understanding gangs hold across national boundaries. Such an approach would enable researchers and policymakers to better understand similarities and differences in gang problems for the purpose of designing responses that would be effective across geopolitical boundaries.

Additionally, these findings, coupled with prior research, suggest that focusing on multiple risk factors will help practitioners identify youth who are at high risk for gang joining, and provide a framework for building gang prevention programs. This strategy is currently being employed by the City of Los Angeles, United States. Approximately a dozen Los Angeles neighborhoods characterized by community risk factors (i.e., social disorganization, high mobility, etc.) associated with gang joining were first identified. Next, youth (and their families) who were exposed to a high number of risk factors associated with gang membership were then identified (through self-report surveys) and recruited for gang prevention programs (73). While the program in Los Angeles is the largest of its kind, and has yet to be evaluated, prior research suggests that prevention programs focused on a number of risk and protective factors have the most success with prevention of gang joining (74). However, additional research that examines the association between gang status and risk and protective factors is needed in the Caribbean prior to implementing similar programs. In this regard, it would be beneficial for researchers across the Caribbean to collaborate on a geographically-based longitudinal study to better understand the health risks faced by Caribbean youth, so that governments and social services can respond most effectively.

Last, the current study found that some prosocial group-based activities that have been traditionally viewed as protective, might in fact increase the likelihood of gang joining in the Caribbean. Future research in the Caribbean should focus on the social mechanisms through which specific risk and protective factors function for gang involvement, in general, and should further examine the effect of peer contagion on gang joining, in particular. If these study's findings are replicated in the future, they suggest that policymakers consider increasing the availability of individual goal-oriented programs, and reducing peer relationship group-based exercises as part of gang prevention efforts.

In addition, future research might also focus on identifying individual and/or group-based activities that promote a "belief in moral order," which the study confirmed is a significant protective factor.

Acknowledgements. Funding for this research was provided by the Ministry of National Security, Trinidad and Tobago. The points of view expressed in this paper are those of the authors alone and do not represent the official policies or positions of the Ministry of National Security, Trinidad and Tobago Police Service, or Arizona State University. The authors would like to thank Todd Herrenkohl, Scott Decker, and William Wells for reviewing and providing substantive feedback on an earlier version of this manuscript. Furthermore, the authors would like to thank Marlene Charles of the Peace Promotion Programme within the Ministry of Education. This research was approved by the Institutional Review Board at Arizona State University (IRB Protocol \#0702001609), United States. 
APPENDIX A. Item dictionary for risk and protective factors in Trinidad and Tobago, 2006

\section{COMMUNITY: Low Neighborhood Attachment}

How much do each of the following statements describe your neighborhood:

I like my neighborhood.

NO! / no / yes / YES!

If I had to move, I would miss the neighborhood I now live in.

$\mathrm{NO}$ / / no / yes / YES!

\section{COMMUNITY: Community Disorganization}

How much does each of the following statements describe your neighborhood:

Crime and/or drug selling

Fights

Lots of empty or abandoned buildings

Lots of graffiti

I feel safe in my neighborhood

NO! / no / yes / YES!

NO! / no / yes / YES!

NO! / no / yes / YES!

NO! / no / yes / YES!

NO! / no / yes / YES!

\section{COMMUNITY: Mobility}

Have you changed homes in the past year (the last 12 months)?

No / Yes

COMMUNITY: Laws and Norms Favorable to Drug Use

How wrong would most adults (over 21) in your neighborhood think it is for young people your age to:

Use marijuana

Drink alcohol

If a kid drank some beer, wine, or hard liquor (for example vodka, whisky, or gin) in your neighborhood, would he or she be caught by the police?

If a kid smoked marijuana in your neighborhood would he or she be caught by the police?

If a kid carried a handgun in your neighborhood would he or she be caught by the police?

Very wrong / Wrong / A little bit wrong / Not wrong at all

Very wrong / Wrong / A little bit wrong / Not wrong at all

NO! / no / yes / YES!

$\mathrm{NO}$ ! / no / yes / YES!

NO! / no / yes / YES!

COMMUNITY: Perceived Availability of Handguns

If you want to, how easy would it be for you to get the following:

A handgun

Very hard / Sort of hard / Sort of easy / Very easy

COMMUNITY: Perceived Availability of Drugs

If you want to, how easy would it be for you to get the following:

Some beer, wine, or hard liquor (for example, vodka, whiskey, or gin)

Some marijuana

Very hard / Sort of hard / Sort of easy / Very easy

Very hard / Sort of hard / Sort of easy / Very easy

\section{COMMUNITY: Opportunities for Prosocial Involvement}

Are sports activities for people your age available in your community?

No / Yes

Are club activities for people your age available in your community?

No / Yes

\section{COMMUNITY: Rewards for Prosocial Involvement}

My neighbors notice when I am doing a good job and let me know about it.

NO! / no / yes / YES!

There are people in my neighborhood who encourage me to do my best.

$\mathrm{NO}$ ! / no / yes / YES

There are people in my neighborhood who are proud of me when I do something well.

NO! / no / yes / YES

\section{SCHOOL: Academic Failure}

Putting them all together, what were your grades like last year?

Mostly 29 \& below / Mostly 30-39 / Mostly 40-59

Mostly 60-79 / Mostly 80-100

\section{SCHOOL: Low Commitment to School}

How interesting are most of your subjects to you?

How important do you think the things you are learning in school are going to be for your later life?

During the LAST FOUR WEEKS, how many whole days of school have you missed because you skipped class?

Now thinking back over the past year in school, how often did you:

Feel that the school work you are assigned is meaningful and important?

Enjoy being in school?

Hate being in school?

Try to do your best work in school?

Very interesting and stimulating / Quite interesting / Fairly interesting / Slightly dull / Very dull

Very important / Quite important / Fairly important / Slightly important / Not at all important

None / 1 / 2 / 3 / 4-5 / 6-10 / 11+

Never / Seldom / Sometimes / Often / Almost Always Never / Seldom / Sometimes / Often / Almost Always

Never / Seldom / Sometimes / Often / Almost Always

Never / Seldom / Sometimes / Often / Almost Always 


\section{APPENDIX A. (Continued)}

\begin{tabular}{|c|c|}
\hline SCALES AND QUESTIONS & RESPONSE CATEGORIES \\
\hline \multicolumn{2}{|l|}{ SCHOOL: Opportunities for Prosocial Involvement } \\
\hline In my school, students have lots of chances to help decide things like class activities and rules. & NO! / no / yes / YES! \\
\hline Teachers ask me to work on special classroom projects. & NO! / no / yes / YES! \\
\hline $\begin{array}{l}\text { There are lots of chances for students in my school to get involved in sports, clubs, and other school } \\
\text { activities outside of class. }\end{array}$ & NO! / no / yes / YES! \\
\hline My teachers notice when I am doing a good job and let me know about it. & NO! / no / yes / YES! \\
\hline The school lets my parents know when I have done something well. & NO! / no / yes / YES! \\
\hline I feel safe at my school. & NO! / no / yes / YES! \\
\hline My teachers praise me when I work hard in school. & NO! / no / yes / YES! \\
\hline
\end{tabular}

\section{FAMILY: Family History of Antisocial Behavior}

Have any of your brothers or sisters ever:

Drank beer, wine, or hard liquor (for example vodka, whiskey, or gin)?

Smoked marijuana?

Taken a handgun to school?

Been suspended or expelled from school?

About how many adults (over 21) have you known personally who in the past year have:

Used marijuana, crack, cocaine, or other drugs?

Sold or dealt drugs?

Done other things that could get them in trouble with the police, like stealing, selling stolen goods,

mugging, or assaulting others, etc?

Gotten drunk or high?
No / Yes / I don't have any brothers or sisters

No / Yes / I don't have any brothers or sisters

No / Yes / I don't have any brothers or sisters

No / Yes / I don't have any brothers or sisters

$0 / 1 / 2 / 3-4 / 5+$

$0 / 1 / 2 / 3-4 / 5+$

$0 / 1 / 2 / 3-4 / 5+$

$0 / 1 / 2 / 3-4 / 5+$

\section{FAMILY: Poor Family Management}

My parents ask if I've done my homework.

Would your parents know if you did not come home on time?

When I am not at home, one of my parents knows where I am and who I am with.

The rules in my family are clear.

My family has clear rules about alcohol and drug use.

If you drank some beer, wine, or hard liquor (for example vodka, whisky, or gin) without your parents' permission, would you be caught by your parents?

If you skipped school would you be caught by your parents?

If you carried a handgun without your parents' permission, would you be caught by your parents?

\section{FAMILY: Family Conflict}

People in my family often insult or yell at each other.

People in my family have serious arguments.

We argue about the same things in my family over and over.
NO! / no / yes / YES
NO! / no / yes / YES!
$\mathrm{NO}$ / / no / yes / YES!
NO! / no / yes / YES!
NO! / no / yes / YES!
NO! / no / yes / YES!
$\mathrm{NO}$ / / no / yes / YES!
NO! / no / yes / YES!

\section{FAMILY: Parental Attitudes Favorable Towards Drug Use}

How wrong do your parents feel it would be for YOU to:

Smoke marijuana?

NO! / no / yes / YES

$\mathrm{NO}$ / / no / yes / YES!

NO! / no / yes / YES!

\section{FAMILY: Parental Attitudes Favorable Towards Alcohol Use}

How wrong do your parents feel it would be for YOU to:

Drink beer, wine, or hard liquor (for example vodka, whiskey, or gin) regularly?

Very wrong / Wrong / A little bit wrong / Not wrong at all

\section{FAMILY: Parental Attitudes Favorable to Antisocial Behavior}

How wrong do your parents feel it would be for YOU to:

Steal something worth more than $\$ 30$ ?

Draw graffiti, write things, or draw pictures on buildings or other property (without the owner's permission)?

Pick a fight with someone?

NO! / no / yes / YES!

Very wrong / Wrong / A little bit wrong / Not wrong at all Very wrong / Wrong / A little bit wrong / Not wrong at all 


\section{APPENDIX A. (Continued)}

\section{SCALES AND QUESTIONS}

\section{FAMILY: Attachment}

Do you feel very close to your mother?

Do you share your thoughts and feelings with your mother?

Do you feel very close to your father?

Do you share your thoughts and feelings with your father?

FAMILY: Opportunities for Prosocial Involvement

My parents give me lots of chances to do fun things with them.

My parents ask me what I think before most family decisions affecting me are made.

If I had a personal problem I could ask my mother or father for help.

\section{FAMILY: Rewards for Prosocial Involvement}

My parents (or those who you consider to be your parents) notice when I am doing a good job and let me know about it.

How often do your parents tell you they're proud of you for something you've done?

Do you enjoy spending time with your mother?

Do you enjoy spending time with your father?

\section{PEER-INDIVIDUAL: Rebelliousness}

I do the opposite of what people tell me, just to get them mad.

I ignore the rules that get in my way.

I like to see how much I can get away with.

\section{PEER-INDIVIDUAL: Early Initiation of Antisocial Behavior}

How old were you when you first:

Attacked someone with the intention of seriously hurting them?

Never / 10 or younger / 11/12/13/14/15/16/17 or older

\section{PEER-INDIVIDUAL: Early Initiation of Drug Use}

How old were you when you first:

Smoked marijuana?

Never / 10 or younger / $11 / 12 / 13 / 14 / 15 / 16 / 17$ or older

\section{PEER-INDIVIDUAL: Early Initiation of Alcohol Use}

How old were you when you first:

Had more than a sip or two of beer, wine, or hard liquor?

Began drinking alcoholic beverages once or twice a month?

Never / 10 or younger / $11 / 12 / 13 / 14 / 15 / 16 / 17$ or older

Never / 10 or younger / 11/12/13/14/15/16/17 or older

\section{PEER-INDIVIDUAL: Attitudes Favorable to Antisocial Behavior}

How wrong do you think it is for someone your age to:

Take a handgun to school?

Steal anything worth more than $\$ 30$ ?

Pick a fight with someone?

Attack someone with the intention of seriously hurting them?

Stay away from school all day when their parents think they are at school?

PEER-INDIVIDUAL: Attitudes Favorable to Drug Use

How wrong do you think it is for someone your age to:

Smoke marijuana?

Very wrong / Wrong / A little bit wrong / Not wrong at all

\section{PEER-INDIVIDUAL: Attitudes Favorable to Alcohol Use}

How wrong do you think it is for someone your age to:

Drink beer, wine or hard liquor regularly?

Very wrong / Wrong / A little bit wrong / Not wrong at all

\section{PEER-INDIVIDUAL: Intentions to Use Drugs}

When I am an adult I will:

Smoke marijuana

NO! / no / yes / YES

\section{PEER-INDIVIDUAL: Intentions to Use Alcohol}

When I am an adult I will:

Drink beer, wine, or liquor

NO! / no / yes / YES

(Continued) 


\section{APPENDIX A. (Continued)}

\begin{tabular}{ll}
\hline SCALES AND QUESTIONS & RESPONSE CAT \\
\hline PEER-INDIVIDUAL: Perceived Risks of Drug Use & \\
\hline How much do you think people risk harming themselves (physically or in other ways) if they: & No risk / Slight \\
$\quad$ Try marijuana once or twice & No risk / Slight \\
Smoke marijuana regularly & No risk / Slight \\
Take one or two drinks of an alcoholic beverage nearly every day & \\
\hline PEER-INDIVIDUAL: Antisocial Peers & \\
\hline Think of your four best friends (the friends you feel closest to). In the past year (12 months), & \\
how many of your best friends have: & \\
Been suspended from school? & $0 / 1 / 2 / 3 / 4$ \\
Carried a handgun? & $0 / 1 / 2 / 3 / 4$ \\
Sold illegal drugs? & $0 / 1 / 2 / 3 / 4$ \\
Stolen or tried to steal a motor vehicle such as a car or motorcycle? & $0 / 1 / 2 / 3 / 4$ \\
Been arrested? & $0 / 1 / 2 / 3 / 4$ \\
Dropped out of school? & $0 / 1 / 2 / 3 / 4$
\end{tabular}

\section{PEER-INDIVIDUAL: Peers Use Drugs}

Think of your four best friends (the friends you feel closest to). In the past year (12 months),

how many of your best friends have:

Used marijuana?

$0 / 1 / 2 / 3 / 4$

\section{PEER-INDIVIDUAL: Peers Use Alcohol}

Think of your four best friends (the friends you feel closest to). In the past year (12 months), how many of your best friends have:

Tried beer, wine, or hard liquor when their parents didn't know about it

$0 / 1 / 2 / 3 / 4$

\section{PEER-INDIVIDUAL: Rewards for Antisocial Involvement}

What are the chances you would be seen as popular if you:

Began drinking alcoholic beverages regularly, what is at least once or twice a month?

Smoked marijuana?

Carried a handgun?

No or very little chance / Little chance / Some chance / Pretty good chance / Very good chance

No or very little chance / Little chance / Some chance /

Pretty good chance / Very good chance

No or very little chance / Little chance / Some chance /

Pretty good chance / Very good chance

\section{PEER-INDIVIDUAL: Depression}

Sometimes I think that life is not worth living

NO! / no / yes / YES!

At times I think I am not good at all.

All in all, I am inclined to think that I am a failure.

In the past year, have you felt depressed or sad MOST days, even if you felt okay sometimes?

NO! / no / yes / YES!

NO! / no / yes / YES!

NO! / no / yes / YES!

\section{PEER-INDIVIDUAL: Sensation Seeking}

How many times have you done the following things:

Done what feels good no matter what.

Done something dangerous because someone dared you to do it.

Never / Yes, but not in the past year / Less than once a month / About once a month / Two or three times a month / Once a week or more

Never / Yes, but not in the past year / Less than once a month / About once a month / Two or three times a month / Once a week or more

Done crazy things even if they are a little dangerous.

Never / Yes, but not in the past year / Less than once a month / About once a month / Two or three times a month / Once a week or more

\section{PEER-INDIVIDUAL: Religiosity}

How often do you attend religious services or activities?

Never / Rarely / 1-2 times a month / About once a week or more

\section{PEER-INDIVIDUAL: Social Skills}

You're looking at CDs in a music store with a friend. You look up and see her slip a CD into her bag. She smiles and says "Which one do you want? Go ahead, take it while nobody's around." There is nobody in sight, no employees, and no other customers. What would you do now?

Ignore her / Grab a CD and leave the store / Tell her to put the $C D$ back / Act like it is a joke, and ask her to put the $C D$ back

(Continued) 


\section{APPENDIX A. (Continued)}

\section{SCALES AND QUESTIONS}

It's 8:00 p.m. on a weeknight and you are about to go over to a friend's home when your mother asks you where you are going. You say "To lime with some friends." She says "No, you'll just get into trouble if you go out. Stay home tonight." What would you do now?

You are visiting another part of the country, and you don't know any of the people who are there. You are walking down the street, and some teenager you don't know is walking toward you. $\mathrm{He}$ is about your size and as he is about to pass you, he deliberately bumps into you and you almost lose your balance. What would you say or do?

You are at a party at someone's house, and one of your friends offers you a drink containing alcohol. What would you do?

\section{RESPONSE CATEGORIES}

Leave the house anyway / Explain what you are going to do with your friends, tell her when you will get home, and ask if you can go out / Not say anything and start watching TV / Get into an argument with her

Push the person back / Say "Excuse me" and keep on walking / Say "Watch where you are going" and keep walking / Swear at the person and walk away

Drink it / Tell you friend "No, thanks, I don't drink" and suggest that you and your friend go and do something else / Just say "No thanks" and walk away / Make up a good excuse, tell your friend you had something else to do, and leave

\section{PEER-INDIVIDUAL: Belief in Moral Order}

I think it is okay to take something without asking if you can get away with it.

I think sometimes it's okay to cheat at school.

It is all right to beat up people if they start the fight.

It is important to be honest with your parents, even if they become upset or you get punished.
NO! / no / yes / YES!

NO! / no / yes / YES!

NO! / no / yes / YES!

NO! / no / yes / YES!

\section{PEER-INDIVIDUAL: Prosocial Involvement}

How many times in the PAST YEAR (12 months) have you:

Done extra work on your own for school?

Never / 1-2 / 3-5 / 6-9 / 10-19 / 20-29 / 30-39 / 40+

\section{PEER-INDIVIDUAL: Rewards for Prosocial Involvement}

What are the chances you would be seen as popular if you:

Defended someone who was being verbally abused at school?

No or very little chance / Little chance / Some chance /

Pretty good chance / Very good chance

\section{PEER-INDIVIDUAL: Interaction with Prosocial Peers}

Think of your four best friends (the friends you feel closest to). In the past year (12 months),

how many of your best friends have:

Participated in clubs, organizations, and activities at school? $\quad 0 / 1 / 2 / 3 / 4$

Made the commitment to stay drug-free?

Tried to do well in school?

$0 / 1 / 2 / 3 / 4$

Liked school?

$0 / 1 / 2 / 3 / 4$

Regularly attended religious services?

$0 / 1 / 2 / 3 / 4$

$0 / 1 / 2 / 3 / 4$

\section{REFERENCES}

1. Sanders B, Lankenau SE. A public health model for studying youth gangs. In: Short J, Hughes L, eds. Studying Youth Gangs. Walnut Creek: Rowman Altamira: 2006; 117-28.

2. Testimony of Adolfo A. Franco, Assistant Administrator, Bureau for Latin American and the Caribbean, USAID on 20 April 2005, US House of Representatives Subcommittee on the Western Hemisphere. Available from http:/ / commdocs.house.gov/committees / intlrel/hfa24054.000/hfa24054 0f.htm. Accessed on 4 February 2010.

3. Reducing violence in selected Central American countries. Available from: http://www. paho.org/English/AD/DPC/NC/vio-3proy.htm. Accessed 10 February 2009.

4. Sander B, Lankenau S, Jackson-Bloom J. A public health study of gang youth in Los Angeles: preliminary analysis. Available from: http://www.allacademic.com//meta/p ml a_apa_research_citation $/ 1 / 8 / 3 / 9 / 7 /$ pages1 83976/p183976-1.php. Accessed 9 February 2009.

5. Decker SH, Weerman FM. European street gangs and troublesome youth groups. Walnut Creek: Rowman Altamira; 2005.

6. Heinemann A, Verner D. Crime and violence in development: A literature review of Latin America and the Caribbean. Washington DC: World Bank: 2006. (World Bank Policy Research Working Paper 4041).

7. Blum RW, Halcón L, Beuhring T, Pate E, Campell-Forrester S, Venema A. Adolescent health in the Caribbean: Risk and protective factors. Am J Public Health. 2003;93(3): 456-60.

8. Ohene S, Ireland M, Blum R. The clustering of risk behaviors among Caribbean Youth. Matern Child Health J. 2005;9(1):91-100.

9. Moser C, Holland J. Urban poverty and violence in Jamaica. Washington DC: World Bank, 1997.
10. United Nations Office on Drugs and Crime, Division for Policy Analysis and Public Affairs. Tenth United Nations survey of crime trends and operations of criminal justice systems, 2005-2006. Available from: http:// www.unodc.org/documents/data-andanalysis/CTS9_by_indicator_public.pdf. Accessed on 18 May 2009.

11. Katz C, Maguire E. Reducing gang homicides in the Besson Street Station District. Arizona State University: Phoenix, Arizona; 2006.

12. Farrington D. Childhood risk factors and risk focused prevention. Cambridge: University of Cambridge; 2006.

13. Committee on Prevention of Mental Disorders, Institute of Medicine. Mrazek PJ, Haggerty RJ, eds. Reducing risks for mental disorders: Frontiers for prevention intervention research. Washington DC: National Academy Press; 1994. 
14. Arthur MW, Hawkins JD, Pollard JA, Catalano RF, Baglioni AJ. Measuring risk and protective factors for substance use, delinquency, and other adolescent problem behaviors: the communities that care youth survey. Eval Rev. 2002;26:575-601.

15. Beyers JM, Toumbourou JW, Catalano RF, Arthur MW, Hawkins J D. A crossnational comparison of risk and protective factors for adolescent substance use: the United States and Australia. J Adol Health. 2004;35(1):3-16.

16. Newcomb MD, Maddahian E, Bentler PM. Risk factors for drug use among adolescents: Concurrent and longitudinal analyses. Am J Public Health. 1986;76(5):525-31.

17. Hawkins JD, Catalano RF, Miller JY. Risk and protective factors for alcohol and other drug problems in adolescence and early adulthood: Implications for substance abuse prevention. Psychol Bull. 1992;112(1):64-105.

18. Hawkins JD, Catalano R, Kosterman R, Abbott R, Hill K. Preventing adolescent health-risk behaviors by strengthening protection during childhood. Arch Ped Adol Med. 1999; 153:226-34.

19. Thornberry T. Membership in youth gangs and involvement in serious and violent offending. In: Loeber R, Farrington DP, eds. Serious and violent offenders: Risk factors and successful interventions. Newbury Park, CA: Sage; 1998. Pp 147-66.

20. Klein M, Maxson C. Street gang patterns and policies. New York: Oxford; 2006.

21. Howell JC. Egley A Jr. Moving risk factors into developmental theories of gang membership. Youth Violence Juv Justice. 2005;3(4): 334-54.

22. Hawkins JD, Catalano RF, Arthur M. Promoting science-based prevention in communities. Addict Behav. 2002;90(5):1-26

23. Maxson CL, Whitlock, ML, Klein MW. Vulnerability to street gang membership: Implications for practice. Soc Serv Rev. 1998;72(1): 70-91.

24. Curry GD, Spergel IA. Gang involvement and delinquency among Hispanic and AfricanAmerican adolescent males. J Res Crime Delinq. 1992;29:273-91.

25. Hill KG, James $\mathrm{CH}$, Hawkins JD, BattinPearson, SR. Childhood risk factors for adolescent gang membership: Results from the Seattle Social Development Project. J Res Crime Delinq. 1999;36:300-22.

26. Gatti U, Tremblay RE, Vitaro F. Youth gangs, delinquency and drug use: A test of the selection, facilitation, and enhancement hypothesis. J Child Psychol Psychiatry. 2005;46(11): 1178-90.

27. Esbensen F, Winfree LT Jr., He N, Taylor TJ. Youth gangs and definitional issues: When is a gang a gang, and why does it matter? Crime Delinq. 2001;47:105-30.

28. Esbensen F, Deschenes EP. A multisite examination of youth gang membership: Does gender matter? Criminology. 1998;36(4):799-827.

29. Thornberry TP, Krohn MD, Lizotte AJ, Smith CA, Tobin KK. Gangs and delinquency in developmental perspective. Cambridge: Cambridge University Press: 2003.

30. Marlow-Ferguson R. World education encyclopedia: A survey of educational systems worldwide. 2nd ed: Farmington Hills, Michigan: Thomson Learning, 2002.
31. UNICEF. At a glance: Trinidad and Tobago. Available from: http://www. unicef.org/ infobycountry/stats_popup5.html. Accessed 8 November 2009.

32. Katz CM, Maguire E. Improving homicide detection rates in Trinidad and Tobago: Phoenix, Arizona: Arizona State University; 2005.

33. Johnson D. Results from the Gonzales IMPACT Study. Manassas: George Mason University; 2006

34. Maguire ER, Bennett RR. Introduction by guest editors. Caribbean J Criminol Public Safety. 2008;13(1):xvii-xxxix

35. Gfroere J, Wright D, Kopstein, A. Prevalence of youth substance use: the impact of methodological differences between two national surveys. Drug Alcohol Depend. 1997; 47:19-30.

36. Kellerman B, Lomuto N, Machan J, Minugh PA. Alabama student survey of risk and protective factors: Demand and needs assessment studies. Birmingham: Alabama Department of Mental Health and Mental Retardation, Substance Abuse Services Division; 2003.

37. Prais SJ. Two recent (2003) international surveys of schooling attainments: England's problems. London: The National Institute of Economic and Social Research; 2005. (Discussion paper no. 258).

38. Wild T, Ragan L, Pim C, Roberts A, PazderkaRobinson $\mathrm{H}$, Horne T, O'Hara P. Tobacco use among Alberta youth: Results from the Alberta Youth Tobacco Survey. Edmonton: University of Alberta; 2003.

39. Bulmer M. Social research in developing countries: Surveys and censuses in the Third World. New York: Routledge; 1993.

40. Harachi TW, Hawkins JD, Catalano RF, Lafazia AM, Smith BH, Arthur MW. Evidence-based community decision making for prevention: Two case studies of Communities that Care. Japanese J Sociol Criminol. 2003; 28:26-37.

41. Beyers JM, Toumbourou J, Catalano R, Arthur M, Hawkins D. A cross-national comparison of risk and protective factors for adolescent substance use: The United States and Australia. J Adol Health. 2004;35:3-16.

42. Hemphill S, Toumbourou J, Catalano RF, Mathers M. Levels and Family Correlates of Positive Adolescent Development: A Crossnational Comparison [online]. Family Matters. 2004;68:28-35. Available from: http:// aifs.gov.au/institute/pubs/fm2004/fm68/ sh.pdf. Accessed on 30 January 2010.

43. Brook J, Morojele N, Pahl K, Brook D. Predictors of drug use among South African adolescents. J Adol Health. 2006;38:26-34.

44. Fairington A. Communities that care: a case study of regeneration from Wales. Crit Public Health. 2004;14(1):27-36.

45. Katz CM, Webb V, Decker S. Using the Arrestee Drug Abuse Monitoring (ADAM) program to further understand the relationship between drug use and gang membership. Justice Q. 2005;22(1):58-88.

46. Farrington DP, Loeber R. Some benefits of dichotomization in psychiatric and criminological research. Crim Behav Ment Health. 2000; 10:100-122.

47. Bond L, Toumbourou JW, Thomas L, Catalano RF, Patton G. Individual, family, school, and community risk and protective factors for depressive symptoms in Adolescents: A comparison of risk profiles for substance use and depressive symptoms. Prev Sci. 2005; 6(2):73-88

48. Williams RL. A note on robust variance estimation for cluster-correlated data. Biometrics. 2000;56:645-6.

49. Belsley D, Kuh E, Welsch R. Regression diagnostics: identifying influential data and sources of collinearity. New York: John Wiley \& Sons; 2002.

50. Gmel, G. Imputation of missing values in the case of multiple item instrument measuring alcohol consumption. Stat Med. 2001;20: 2369-81.

51. Maxson CL, Whitlock ML, Klein MW. Gang joining and resistance: Who can "just say no" to gangs? Final report submitted to Administration of Children and Families, U.S Department of Health and Human Services. Los Angeles: University of Southern California; 1997.

52. Esbensen F, Huizinga D, Weiher AW. Gang and non-gang youth: Differences in explanatory factors. J Contemp Crim Justice. 1993; 9(2):94-116.

53. Huizinga D, Weiher AW, Menard S, Espiritu $\mathrm{R}$, Esbensen F. Some not so boring findings from the Denver Youth Survey. Institute of Behavioral Science, Boulder, University of Colorado; 1998.

54. Decker S, Winkle BV. Life in the gang. New York: Cambridge; 1996.

55. Peterson D, Taylor T, Esbensen FA. Gang membership and violent victimization. Justice Q. 2004;21(4):793-815.

56. Bursik RJ Jr., Grasmik HG. Neighborhoods and crime: The dimensions of effective community control. New York: Lexington; 1993.

57. Sampson RJ, Raudenbush SW, Earls F. Neighborhoods and violent crime: A multilevel study of collective efficacy. Science. 1997;277: 918-24.

58. Shaw CR, McKay HD. Juvenile delinquency and urban areas. Chicago: University of Chicago Press; 1942.

59. Colin D. Dubinsky W, Derrick C. Latin America and the Caribbean selected economic and social data. Washington DC: United States Agency for International Development; 2007.

60. Maharaj RG, Nunes P, Renwick S. Health risk behaviors among adolescents in the Englishspeaking Caribbean: a review. Child Adolesc Psychiatry Ment Health. 2009;3(10):1-12.

61. Miller WB. The impact of a "total community" delinquency control project. Social Problems. 1962;10(2):169-91.

62. Spergel IA. Community action research as a political process. In: Spergel IA, ed. Community Organization: Studies in Constraint. Beverly Hills: Sage Publications; 1972. Pp 231-62.

63. Thrasher F. The boys' club and juvenile delinquency. Am J Sociol. 1936;41:66-80.

64. Klein MW. Street gangs and street workers. Englewood Cliffs, NJ: Prentice-Hall; 1971.

65. Spergel IA. The violent youth gang in Chicago: A local community approach. Soc Serv Rev. 1986;60:94-131.

66. Dishion TJ, McCord J, Poulin F. When interventions harm: Peer groups and problem behavior. Am Psychol. 1999;54(9):755-64.

67. Cho H, Hallfors DD, Sanchez V. Evaluation of a high school peer group intervention for at- 
risk youth. J Abnorm Child Psychol. 2005; 33(3):363-74.

68. Dishion TJ, Dodge KA. Peer contagion in interventions for children and adolescents: Moving towards an understanding of the ecology and dynamics of change. J Abnormal Child Psychol. 2005;33(3):395-400.

69. Leve LD, Chamberlain P. Association with delinquent peers: Intervention effects for youth in the juvenile justice system. J Abnormal Child Psychol. 2005;33(3):339-47.

70. Klein MW. The America street gang: Its nature, prevalence, and control. New York: Oxford University Press; 1995
71. Haines $\mathrm{K}$, Case $\mathrm{S}$. The rhetoric and reality of the 'Risk Factor Prevention Paradigm' approach to preventing and reducing youth offending. Youth Justice. 2008;8(1): 5-20.

72. Catterall JS. Risk and resilience in student transitions to high school. Am J Educ: 1998; 106(2):302-333.

73. Villaraigosa A. Mayor Villaraigosa names Guillermo Cespedes new director of gang reduction and youth development. Available from: http://mayor.lacity.org/PressRoom/ PressReleases/LACITYP 006150. Accessed 30 January 2010.
74. National Research Council and Institute of Medicine. Community programs to promote youth development. Washington, DC: National Academy Press; 2002.

Manuscript received on 30 June 2009. Revised version accepted for publication on 21 December 2009.

RESUMEN Objetivos. Examinar la prevalencia de la participación en pandillas, los factores de riesgo y los factores protectores asociados con la participación en pandillas, y la asociación entre la participación en pandillas y la exposición a diversos factores de riesgo

Factores de riesgo y factores protectores asociados con la participación de

los adolescentes en pandillas en Trinidad y Tabago

Métodos. Entre marzo y junio del 2006 se administró un instrumento de encuesta a 2206 estudiantes matriculados en 22 escuelas públicas urbanas de alto riesgo. La encuesta medía 30 factores de riesgo y 13 factores protectores en cuatro ámbitos diferentes: la comunidad, la escuela, la familia y los compañeros individuales, además de los niveles de consumo de alcohol o drogas y la delincuencia.

Resultados. Cerca de 7,7\% de los adolescentes informaron que pertenecían a una pandilla, 6,8\%, habían sido miembros de una pandilla y 6,2\% lo eran en la actualidad. La participación en una pandilla se asociaba con la percepción de disponibilidad de pistolas, la movilidad residencial, tener padres que aprobaran la conducta antisocial, el inicio temprano de comportamientos antisociales, la intención de consumir drogas, tener compañeros antisociales y tener compañeros consumidores de drogas. Los adolescentes dotados de habilidades sociales, los que creían en un orden moral y los que se relacionaban con compañeros prosociales presentaban de forma significativa menos probabilidades de participación en una pandilla. Además, la probabilidad de participación en una pandilla se incrementaba si aumentaba el número de factores de riesgo. Conclusiones. La prevalencia de la participación en pandillas en los adolescentes de las escuelas públicas de Trinidad y Tabago es aproximadamente la misma que la observada en Estados Unidos, Canadá y Europa occidental, pero es necesario ampliar la investigación. Aunque los factores de riesgo asociados con la participación en pandillas estaban presentes en los cuatro dominios, la probabilidad de que los factores de riesgo relacionados con los compañeros individuales se asociaran con la participación en una pandilla era desproporcionadamente alta. Las estrategias más eficaces para prevenir la participación en pandillas tal vez sean aquellas que se centran en múltiples factores de riesgo y hacen hincapié en los factores relacionados con los compañeros individuales.

Palabras clave Adolescente; conducta del adolescente; problemas sociales; conducta de masa; factores de riesgo; conducta de reducción del riesgo; Trinidad y Tobago; Región del Caribe. 